\title{
MOTIVATIONS AND JOB REPRESENTATIONS OF PROSPECTIVE PHYSICAL EDUCATION TEACHERS STARTING THEIR VOCATIONAL TRAINING
}

\author{
Madisson Bodart, Dimitri Cauchie, \& Marielle Bruyninckx \\ Department of Human Development and Data Processing, University of Mons (Belgium)
}

\begin{abstract}
The teaching career-choice can be mainly explained by various intrinsic motivations (Berger \& D'Ascoli, 2011) but also by a high sense of personal efficiency (Watt \& Richardson, 2007). In the case of physical education teaching, the choice is often made by students who previously had a personal affinity for a sport, for which they imagine professional developments (Carlier et al., 2003). Men' choice seems, however, to be more focused on the sports skills to be achieved (Roux-Perez, 2004).

This paper summarizes the results of an exploratory research based on a questionnaire. Our main objective was to analyze the motivations, the personal efficiency and the job representations held by physical education students at the beginning of their vocational training. In order to answer our research questions, 254 subjects (174 men and 80 women), studying in two institutions of higher education, were surveyed and a descriptive cross-sectional analysis was then conducted.

Our results allow us to conclude that, broadly speaking and regardless of gender, physical education students are mainly motivated by intrinsic factors. Through their future profession, they search for a personal achievement and an improvement of their knowledge. They generally have a high sense of personal efficiency although women sometimes feel less "able" than men to teach physical education at the beginning of their training. Finally, the students agree on the qualities needed to the physical education teacher and they often hold their job representations close to that of an "educator" and "animator".
\end{abstract}

Keywords: Physical Education, vocational training, motivation, representations, personal efficiency.

\section{Introduction}

The teaching career-choice can be mainly explained by personal factors (types of motivation, beliefs in one's abilities, prior personal appeal for a sport ...) and by preconceptions of the job that may vary from one individual to another (Bandura, 2003; Carlier et al., 2003 ; Roux-Perez, 2004 ; Berger \& D’Ascoli, 2011). When a choice of educational orientation has to be made, individuals calculate the costs, benefits and risks associated with it (Franquet, Friant \& Demeuse, 2010). But the way the orientation is selected (free choice or under the influence of relatives for example) may later have positive or negative consequences on motivation (Brasselet \& Guerrien, 2010).

The concept of motivation is used in the sector of education and training to explain people's attitudes and performance (Toffoli, 2003). The model of self-determination (Deci \& Ryan, 2000) describes the motivational dynamics that explain an individual engages or not in an activity. It defines different types of motivation that are differentiated according to the degree of self-determination of people, that is to say the degree to which they feel free or forced to perform an activity. Three main motivations can be highlighted: the amotivation, the extrinsic motivation and the intrinsic motivation.

Amotivation means a total lack of motivation for the activity. Extrinsic motivation occurs when the individual performs the activity without an optimal personal interest. It refers to behavior that is driven by external rewards or by the wish of avoiding unpleasant consequences. This type of motivation is characterized by four forms of regulation: external, introjected, identified and integrated. The last two types (identified and integrated) are often studied in the literature without any real distinction. Finally, the intrinsic motivation means that an activity is voluntarily carried out only for the pleasure, the satisfaction and the interest that it provides. It is the highest degree of self-determination, characterized by several types of intrinsic motivation: knowledge, achievement, and stimulation (Blais et al., 1993; Deci \& Ryan, 2000). 
Beliefs about one's own abilities also play an important role when choosing a teaching career (Watt \& Richardson, 2007). Self-efficacity is indeed a core-concept for motivation, search of well-being and personal accomplishment (Bandura, 2003). In the same way, self-representation of the daily experience has an effect on the motivation because it provides objective and subjective information about the chosen profession (Postic, Le Calve, Joly \& Beninel, 1990).

\section{Methodological approach and sample}

The paper presents the results of an exploratory research conducted among 254 students attending training courses in two French-speaking Belgian higher education institutions. The sample is made up of 174 men $(68.50 \%)$ and 80 women $(31.50 \%)$, enrolled in the different levels of the 3-year training. The proportion of women who choose physical education is significantly lower than that of men, although this difference is much lower at the end of training (women represent $29.84 \%$ of students at the beginning of the cursus against $42.55 \%$ at the end).

By using a global questionnaire, we wanted to analyze their motivations (according to the Scale of Motivations in Education - EMS, Vallerand et al., 1989), their feeling of personal efficiency (Bandura, 2003) and their job representations (as suggested by Carlier et al., 2003). Each item in the questionnaire was associated with a Likert scale ranging from level 0 (strongly disagree / not at all important) to level 10 (strongly agree / very important). A global score is obtained by summing the different so-obtained values. The statistical treatments used to analyze the collected data then allowed us to evaluate similarities and differences between the students.

\section{Main results}

The results show that our students are essentially motivated by intrinsic motivational factors. Through their profession, they essentially seek for a form of personal achievement $(\mathrm{m}=8.06)$, stimulation $(\mathrm{m}=7.98)$ and knowledge $(\mathrm{m}=7.72)$. They indeed enjoy transmitting their sports skills, deepening their knowledge in sport and exceling in the different disciplines of training.

In contrast, they attribute a moderate importance to extrinsic motivations with external or introjected regulation (respectively, $\mathrm{m}=5.55$ and $\mathrm{m}=5.25$ ) even though their diploma will effectively allow them to have a relatively well paid job. Similarly, showing that they are able to succeed in their studies remains a non-central motivation.

Table 1. Motivations of our subjects (mean and standard deviation in the whole sample).

\begin{tabular}{|l|c|c|}
\hline & \multicolumn{2}{|c|}{ Whole sample } \\
\hline Motivations & Mean $(\mathbf{m})$ & Standard deviation $(\boldsymbol{\sigma})$ \\
\hline Intrinsic motivation toward accomplishment & 8.06 & 1.20 \\
\hline Intrinsic motivation toward stimulation & 7.98 & 1.15 \\
\hline Intrinsic motivation toward knowledge & 7.72 & 1.26 \\
\hline Extrinsic motivation with external regulation & 5.55 & 1.79 \\
\hline Extrinsic motivation with introjected regulation & 5.25 & 1.80 \\
\hline Extrinsic motivation with identified regulation & 3.59 & 2.16 \\
\hline Amotivation & .94 & 1.53 \\
\hline
\end{tabular}

Our analyzes highlight that all students have good confidence in their own abilities. They feel able to succeed in their studies $(\mathrm{m}=7.78)$ and to become a good physical education teacher $(\mathrm{m}=8.19)$. They also believe in their own sporting skills $(\mathrm{m}=7.59)$. Let's add that they believe more and more in their abilities to later exercise their profession as they progress in their training.

Table 2. Feeling of perceived self-efficacy of our subjects (mean and standard deviation in the whole sample).

\begin{tabular}{|l|c|c|}
\hline & \multicolumn{2}{|c|}{ Whole sample } \\
\hline Perceived self-efficacy & Mean $(\mathbf{m})$ & Standard deviation $(\boldsymbol{\sigma})$ \\
\hline Feeling able to become a good physical education teacher & 8.19 & 1.48 \\
\hline Feeling able to succeed in their studies & 7.78 & 1.69 \\
\hline Believe in their own sporting skills & 7.59 & 1.38 \\
\hline
\end{tabular}

Finally, students think that a physical education teacher must also be a good "educator" $(\mathrm{m}=8.10)$ and an "animator" ( $m=7.27)$ who have to convey positive values, ensure the social balance of the students while releasing stress in an entertaining way. On the other hand, students less link the physical education teacher with coaching $(\mathrm{m}=5.53)$. They will fewer expect their pupils to outdo themselves and achieve accurate performance. 
Table 3. Job representations (mean and standard-deviation of the whole sample).

\begin{tabular}{|l|c|c|}
\hline & \multicolumn{2}{|c|}{ Whole sample } \\
\hline Job representations & Mean $(\mathbf{m})$ & Standard deviation $(\boldsymbol{\sigma})$ \\
\hline Educator & 8.10 & 1.16 \\
\hline Animator & 7.27 & 1.35 \\
\hline Coach & 5.53 & 1.87 \\
\hline
\end{tabular}

\section{Conclusion}

Our results allow us to conclude that, broadly speaking and regardless of gender, physical education students are mainly motivated by intrinsic factors. Through their future profession, they search for a personal achievement, a stimulation and an improvement of their knowledge. They generally have a high sense of personal efficiency although women sometimes feel less "able" than men to teach physical education at the beginning of their training. Except for this fact, the results show that the motivations of our prospective teachers of physical education little differ while progressing in the vocational training. Finally, the students agree on the qualities needed to the physical education teacher and they often hold their job representations close to that of an "educator" and "animator".

In conclusion, students share quite similar and globally "harmonized" motivations, feelings of self-efficacy and job pre-conceptions. Two explanatory hypotheses can be found to explain this observation: either a "typical profile" is necessary when choosing this type of cursus or a light "smoothing" effect occurs during the training. These hypotheses should be more qualitatively analyzed in future longitudinal research.

\section{References}

Bandura, A. (2003). Auto-efficacité : le sentiment d'efficacité personnelle (J. Lecomte, Trad.). Paris: De Boeck.

Berger, J-L., \& D’Ascoli, Y. (2011). Les motivations à devenir enseignant : revue de la question chez les enseignants de première et deuxième carrière. Revue française de pédagogie, 175, 113-146.

Blais, M., Brière, N., Lachance, L., \& Riddle, A. (1993). L'inventaire des motivations au travail de Blais. Revue québécoise de psychologie, 14(3), 185-215.

Brasselet, C., \& Guerrien, A. (2010). Sentiment de liberté et influence dans la décision d'orientation scolaire: effets sur la motivation scolaire des élèves en classe de première. L'orientation scolaire et professionnelle, 39(4).

Carlier, G., Gaspard, L., Gérard, P., Renard, J-P., Cloes, M., Laraki, N., Lenzen, B., \& Piéron, M. (2003). Adéquation entre les formations existantes en éducation physique, les motivations des étudiants et les différents débouchés professionnels. Le Point sur la Recherche en Education, Louvain-la-Neuve \& Liège: Université catholique de Louvain \& Université de Liège.

Deci, E.L., \& Ryan, R.M. (2000). The "What" and "Why" of goal pursuits: Human needs and the self-determination theory. Psychological Inquiry, 11(4), 227-268.

Franquet, A., Friant, N., \& Demeuse, M. (2010). (S') orienter dans l'enseignement secondaire technique et professionnel en Communauté française de Belgique: la part du choix. L'orientation scolaire et professionnelle, 39(4).

Postic, M., Le Calve, G., Joly, S., \& Beninel, F. (1990). Motivation pour le choix de la profession d'enseignant. Revue française de pédagogie, 91, 25-36.

Roux-Perez, T. (2004). L'identité professionnelle des enseignants d'EPS: entre valeurs partagées et interpretations singulières. Staps, 63, 75-88.

Toffoli, D. (2003). De la théorie à la pratique: appliquer des modèles cognitifs de la motivation dans un centre de langues. ASP, 41-42, 99-114.

Vallerand, R. J., Blais, M. R., Brière, N. M., \& Pelletier, L. G. (1989). Construction et validation de l'échelle de motivation en éducation (EME) (Construction and validation of the Motivation toward Education Scale). Canadian Journal of Behavioural Science / Revue canadienne des sciences du comportement, 21(3), 323-349.

Watt, H., \& Richardson, P. (2007). Motivational factors influencing teaching as a career choice: development and validation of the FiT-choice scale. The Journal of Experimental Education, 75(3), 167-202. 